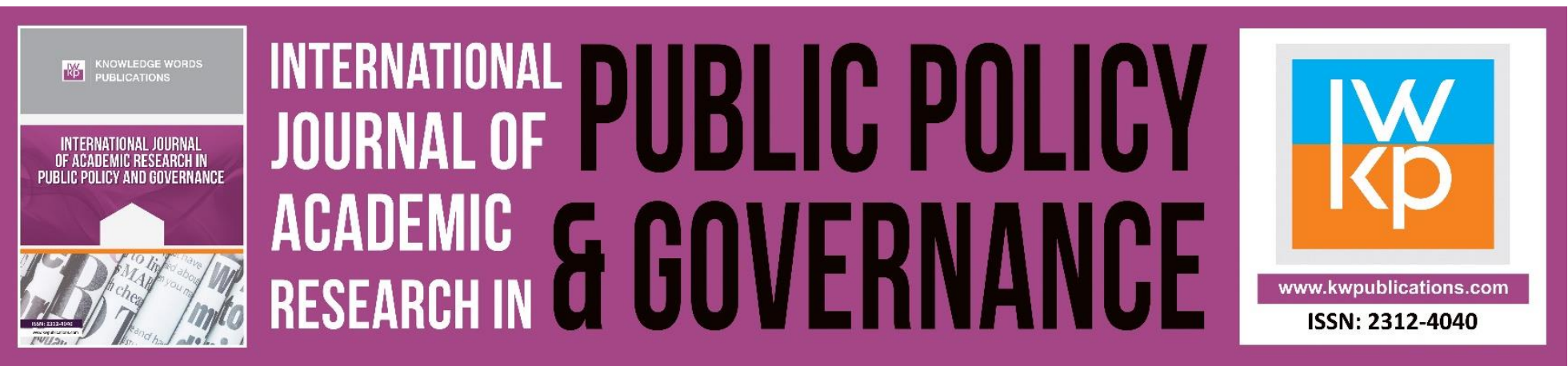

\title{
Can China Rise to the Position of the World Most Powerful Nation? Challenges and Prospects
}

Adekunle Daoud Balogun, Mohammed Olalekan Moyosore, Abdullahi Ayoade Ahmad and Abdul Wasiu Amoo Ishaq

To Link this Article: http://dx.doi.org/10.46886/IJARPPG/v7-i1/7174

DOI:10.46886/IJARPPG/v7-i1/7174

Received: 08 January 2020, Revised: 13 February 2020, Accepted: 16 March 2020

Published Online: 28 April 2020

In-Text Citation: (Balogun et al., 2020)

To Cite this Article: Balogun, A. D., Moyosore, M. O., Ahmad, A. A., \& Ishaq, A. W. A. (2020). Can China Rise to the Position of the most World Powerful Nation? Challenges and Prospects. International Journal of Academic Research in Public Policy and Governace, 7(1), 50-78.

Copyright: (C) 2020 The Author(s)

Published by Knowledge Words Publications (www.kwpublications.com)

This article is published under the Creative Commons Attribution (CC BY 4.0) license. Anyone may reproduce, distribute, translate and create derivative works of this article (for both commercial and non-commercial purposes), subject to full attribution to the original publication and authors. The full terms of this license may be seen at: http://creativecommons.org/licences/by/4.0/legalcode

\section{Vol. 7, No. 1, 2020, Pg. 50 - 78}

Full Terms \& Conditions of access and use can be found at https://kwpublications.com/pages/detail/publication-ethics 


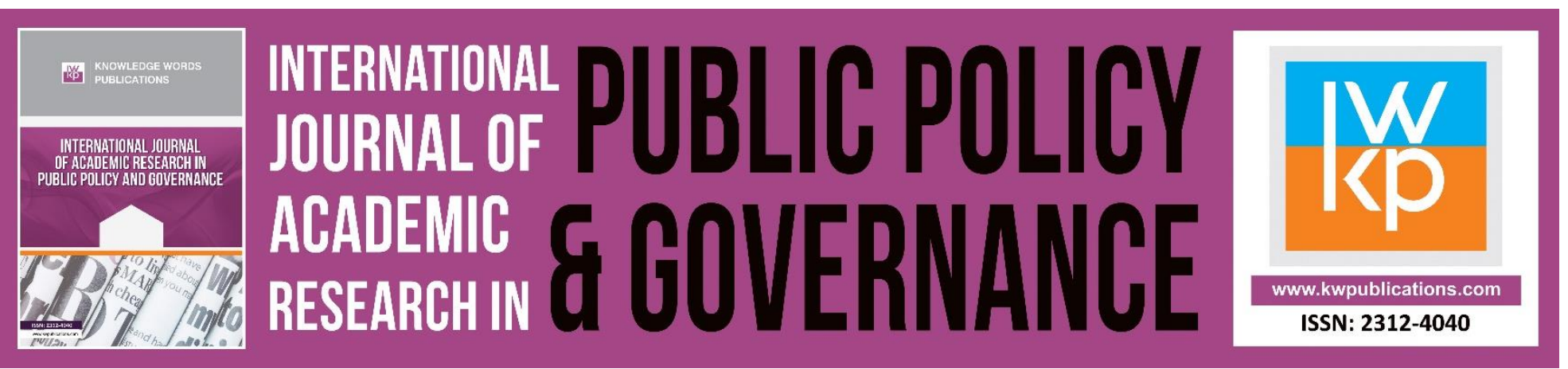

\title{
Can China Rise to the Position of the World Most Powerful Nation? Challenges and Prospects
}

\author{
Adekunle Daoud Balogun ${ }^{1}$, Mohammed Olalekan Moyosore', \\ Abdullahi Ayoade Ahmad ${ }^{2}$ and Abdul Wasiu Amoo Ishaq ${ }^{2}$ \\ ${ }^{1}$ Faculty of Law and International Relations (UNISZA), ${ }^{2}$ Faculty of Law and International Relations \\ (UNISZA), ${ }^{3}$ Faculty of Law and International Relations (UNISZA), ${ }^{4}$ Faculty of Arts and International \\ Relations (UNIABUJA)
}

\begin{abstract}
China, the current world's largest populated country is located in East of the Asian continent on a landmass of $(9,596,961 \mathrm{~km})(3,705,407$ miles $)$ that makes her the third world largest land area after Russia and Canada. China's current population is $(1,427,647,786)$ in 2018 and running its economy at a GDP of US\$12.24 Trillion in 2017. Comparatively, both the USA and China are highly competitive on the issue of the World economic hegemony position, particularly in view of the current Chinese economic progress. Many factors make a nation hegemonic power. With changes in international affairs, different factors are being fashioned as prerequisites for hegemonic power. Theoretically, a large growing economy, dominance in the technological sector and advanced military power, landmass, sovereignty, and large human resources. China is becoming relevant in most of these conditions. However, U.S. has been for a long time the single hegemon since World War II. The influence burgeons stronger particularly, after the Cold War and the fall of the Soviet Union that ended a multipolar world order. However, the research after analyzed other factors, found that America is still strongly relevant as hegemonic power. It is found there are challenges confronting the U.S. in maintaining the position while there are marked indications that China may become a world hegemon in the far future should upward trends in economic prospects persist. However, China's human rights records, her diplomatic relations with some Asian countries that are linked to the South China Sea issues, and her relationship with her extended states like Hong Kong, Taiwan, Tibet, Macao including the clampdown on the people of Xinjiang on the basis of their Islamic religious belief are serious concerns that must be addressed. China should devise scientific method to study, forecast, prevent and manage natural disaster and health issues of pandemic or epidemic context like SARS and Covid-19 that are disastrous to economic progress. The study is a library research. It sources data in secondary archives, government information, books, published journal articles, online materials, and a few other academic sources.
\end{abstract}

Keywords: China's Rise, Hegemonic Power, U.S., Challenges, Prospects. 
INTERNATIONAL JOURNAL OF ACADEMIC RESEARCH IN PUBLIC POLICY AND GOVERNANCE Vol. 7, No. 1, 2020, E-ISSN: 2312-4040 ๔ 2020 KWP

\section{Introduction}

Many scholars have written and published books, articles and conference papers on the concept and context of hegemony and the common national interest of one nation or the other to become hegemonic power should any one meets the required criteria. This study found that there have been many analysis of what hegemons meant to be and what it did in history. However, they all focused on the countries located in the west such as Portugal, Holland, United Kingdom and the current hegemon, the United States of America. This study investigates critically U.S. Hegemonic power and the struggle of a closer hegemonic pretender.

Conversely, the study under context focuses on investigating the sustainability of United States of America as current hegemon from the west. The research focus on tendencies for China to become a hegemonic pretender and the first ever competing for such global position from the Asian continent where it maintains regional hegemon.

Hegemony is understood to mean "power dominance" exercised by one organization or a country at regional, continental or global level over others. The Advanced Learner's Dictionary defines hegemony as the situation of being the powerful or the strongest, and use the leverage to control others especially as a country (Cambridge Advanced Learner's Dictionary (2008). The use of this concept is critically observed and its practice is palpable among individuals, groups, organizations as well as countries where the powerful economic, military, political, and cultural (or "soft") (Miller, 2005) are measures including other factors as means to command and dominate the affairs of others in such a way to achieve interests.

The study under context intends to find the reasons for hegemonic aspiration of China and the necessity for U.S. to empower itself to evade the possibility of being ousted as superpower. Therefore, the need for this study is imperative. The policy implication is meant for the major powers to not only celebrate the sentiment of being a regional or global power for mere propaganda but to see the position as absolute need for promoting the welfare, peace, progress and universal safety of mankind. The policy and decision-makers should make proper use of leadership position not only for self or national interest but also for the well-being of the people of other nations in line with neoliberal agenda to make the world a peaceful place for all.

\section{Studies in Decades on Hegemonic Power of US and China as Pretender}

According to Lyman (2005) the time of Napoleon, leaders have been predicting China as a potential superpower. The scholar depicts China's aspiration for such global power as unrealistic in 2005, about one and half decades ago. In 2003, China's GDP (by exchange-rate measures) totaled US\$1.159 trillion and ranked sixth in the world, behind France, Britain, Germany, Japan, and the United States $\$ 10,065$ trillion). In 2003, China ranked ninth, supplying 3.5 per cent while the United States shares 14.7 per cent and the European Union accounted for 16.8 per cent of the world's export volume. This study was published in 2005, more than fifteen years ago. However, the study couldn't predict the possible future development but it sincerely suggested the possibility of China as a superpower in the nearest future in line with the study under context that shows China's GDP has surpassed that of France, Britain, Germany, Japan, to become world $2^{\text {nd }}$ highest GDP since the last fifteen years of the study. Beeson (2009) shared a similar idea with (Miller, 2005) that the birth of hegemonic leadership in East Asia is unlike for few reason such as lack of requisites material strength of the U.S., lack of consensus of vision and ideology with no coalesce of supportive states while elite lack the legitimacy of discourse to win Chinese support. 
INTERNATIONAL JOURNAL OF ACADEMIC RESEARCH IN PUBLIC POLICY AND GOVERNANCE Vol. 7, No. 1, 2020, E-ISSN: 2312-4040 ๔ 2020 KWP

Nabers (2010) concluded in his study entitled: Power, leadership, and hegemony in international politics: the case of East Asia that a political force hegemonic power survives but for some time, hence institutionalization of the East Asian regionalism had already gained ground to the point that it is irreversible for the foreseeable. This is another study of about a decade focused on power, leadership and hegemony.

\section{Recent Studies on the U.S. Hegemonic Power and China as hegemony Pretender}

Based on the entire population of Nobel laureates in science from 1901 to 2017, Heinze et al. (2019) found, in a study that, North America's rise as global power in science started in the 1920s and consolidated in 1970s but in 2000, its scientific hegemony witnessed a downward trend as its share of laureates across disciplines dropped. The research in its further findings explained that:

North America has become apparently less effective since 2010 in transferring capacities for conducting ground-breaking research from one generation of scientists to another.

Heinze et al. (2019)

North America's scientific hegemony has often been attributed to the organizational design of its research universities, which compete more actively for scientific talent and adopt scientific innovations faster than universities and research institutions in Europe (and elsewhere). In another view, it is observed that while the US is busy with excitement derived in waging wars with some developing countries as custodian of the position of world superpower, China is busy, strategically penetrating with its soft power capacity in Africa and Asia axis. It does this, predominantly with its Road Belt Initiative and carefully building diplomatic and economic relations to gain prospect as well as selling its ideologies. The Chinese advances may be said to have paved the way for the furtherance of U.S. decline as argued by recent study (Zou \& Jones, 2020). However, Biegon (2020) considers it as important notice that the reason why U.S. authorities continue to give out succor to its allies is a way to sell the belief to individuals, organizations and allies across the globe that US is still capable and strongly in control as the world hegemonic power. However, though, the author finds that it is a system the US can no longer sustain with the weakness in neoliberal ideologies and principles.

Recently, signs of weakness of U.S. as superpower continued to surface during the outbreak of Covid19 pandemic across the globe. For instance, the Foreign Policy (2020 March 3) reported that on April 1,2020 , Taiwan announced it would donate 10 million masks to the world's neediest countries -this includes an additional 2 million masks to the United States in an expanded collaboration effort. The Taiwanese Ministry of Foreign Affairs also handed 400,000 masks over to the United States for the month of April in a way to sympathize with her as it was hard hit with the pandemic that infected over 1.5 million Americans and over 100, 000 deaths.

The President of America, Donald Trump turned to India for the supply of the Hydroxychloroquine (a medicine the WHO did not confirm as absolute cure for Covid-19 because of some identified side effects). It is reported by Forbes (2020) that the Trump Administration has turned to India for this drug because India holds the lion's share of the hydroxychloroquine production market, and manufactures $70 \%$ of the world's supply. The former American President, Jimmy Carter lamented in Common Oceans (2019 April 18) that: 
INTERNATIONAL JOURNAL OF ACADEMIC RESEARCH IN PUBLIC POLICY AND GOVERNANCE Vol. 7, No. 1, 2020, E-ISSN: 2312-4040 ๑ 2020 KWP

China's peace dividend has allowed and enhanced its economic growth. "How many miles of high-speed railroad do we have in this country (USA)?" he asked. China has around 18,000 miles $(29,000 \mathrm{~km})$ of high speed rail lines while the US has "wasted, I think, US\$3 trillion" on military spending. According to a November 2018 study by Brown University's Watson Institute of International and Public Affairs, the US has spent US\$5.9 trillion waging war in Iraq, Syria, Afghanistan, Pakistan and other nations since 2001. "It's more than you can imagine," Carter said of U.S. war spending. "China has not wasted a single penny on war, and that's why they're ahead of us. In almost every way."

(Former President, Jimmy Carter, 2019)

From these backdrops, U.S. has allowed propaganda, power, American exceptionalism to override the values that validate her hegemonic position. This study argues that a major war of confrontation between both actors seem impossible in views of the fact that what seem present among them is a cooperative rivalry as propagated by Professor Nye in spite of the observation that the two nations are entering a wane. He mentioned that in the past, the Soviet and US never entered into a major war despite a high level of nuclear tension. China and the United States have challenging areas of interest that need strategic partnership and interdependence. Similarly, the U.S. national security will require the sharing of power with China on global issues and not implementing power over China. Those grey areas are impossible to address without each other's active proffering solution to issues threatening the world's peace such as illicit drugs, terrorism, climate change and infectious diseases such as the recent Covid-19 that ravaged the world with immeasurable setback on global economic prospects and social fabrics. The lesson learned from the unprecedented lockdown across the world has its destructive toll on the economy with resultant effect on the general well-being of mankind.

\section{The Gaps in the Study}

The gaps created by this study border on the fact that China in almost two decades was identified as fifth economy and most studies strongly theorized that China could not become a world power soon. Many of the scholars did not foresee what roles the strategic power of Chinese leadership, technology and determination of people with honest display of patriotism, nationalism coupled with strict outlawing of social vices could play. Additionally, discipline across china under a strict controlled autocratic or dictatorial government of the Communist Party of China (CPC), the China's ruling party could play as a game changer. After two decades, China has now clinched the world $2^{\text {nd }}$ position in GDP as found by most recent studies due to many economic, political and social advances. Therefore, this development is significant and worthy of appraisal in scholarly articles as a new paradigm shift in the world's framework for economic development and hegemonic leadership. Critically, some of the weaknesses identified with US as the hegemony were upheld by China, translated to advantages which helped her to have leverage and become socially and economically relevant across the globe. The key among such issues was the identified finding of declining in North American scientific research. Heinze et al. (2019) found that North America has become apparently less effective since 2010 in transferring capacities for conducting ground-breaking research from one generation of scientists to another since 2000s while Europe and the Asia-Pacific region seem to be catching up. Similarly, the US under Donald Trump's withdrawal of funding of the environmental degradation and global warming program has its defect on American hegemonic leadership. Chemnick and Frank (2020) in E\&E news on (scientificamerica.com) mention that the 2021 Donald Trump administration's 
budget made deep reductions in U.S. support for multilateral and bilateral partnerships on the environment, sustainable landscapes, forestry and other issues. The abrupt withdrawal justifies the claims in some studies that US is gradually losing the grip of power at global level while China uses the opportunity to fully participate with other major power to rescue the planet from depletion. If the weakness in scientific findings takes a further downward trend according to studies and finding, the research under context found that the global leadership of U.S. may be in jeopardy. The finding of the study was vindicated when a report was published that the medical kits and medications to prevent Coronavirus pandemic were sourced outside the US despite its enormous resources dedicated to scientific research and health sector (Forbes, 202).

\section{Literature Review}

\section{What Does the Hegemon Do?}

The hegemon as a superpower is expected to shoulder a lot of responsibilities for its nation as well as for the rest countries of the world at best level it could afford because the rest of the world have recognized the hegemon as their leader who has more, gain more and expected to give out benefits to the less privileged countries to gain support for the success of her leadership. According to Vincent Ferraro (2010):

The hegemon should persuade other states forcefully to support the system. Hence, the US system garners support from many countries for acceptance and practice of democracy and capitalism. It propagates and defends the basic human rights and free trade. These ideologies are beneficial to other countries and their institutions... Therefore, free trade concept is a crucial phenomenon US must continue to protect for good irrespective of situation and should implement protectionism as caution.

The author maintains further that the advent of new technologies and scientific inventions tilted power and it became unstable within the system. In the event of erosion or weakness of economic and technology, the dominant state would inevitably be faced with deadly challenges on its global leadership position. Such a situation could motivate hegemonic pretenders to reap the benefits if hegemon leadership system is observed to be non-inclusive.

\section{Why Hegemon Is Created?}

A hegemon is a surviving powerful nation. For instance, the hegemonic power of the United Kingdom or Great Britain declined after WWII. There were two main reasons. The first was the difficulty of controlling the colonies with growing decolonization efforts, because of the changing times, and other colonies gaining their independence. Hence, transition of hegemony power was reached between Britain and U.S. A world Superpower is expected to plan, direct and support world affairs to project and implement solution to emerging challenges in (health, environment, education, food, insurgency, border disputes, provide support for the poor nations with security in all dimensions etc.) with her wealth and all necessary resources. Hegemon must also secure strong relations with other countries to create a world order to make the world a peaceful, controllable and better place for all and sundry. A Superpower could request military assistance or acquiring military base from other nations on a certain set of agreement and principles to enable her spy on and contain countries or non-state actors who are threat to peace and stability or who are anti-hegemon's ideologies and policies. U.S. has almost 800 military bases around the world while 60,000 and 70,000 U.S. troops are 
in the Middle East according to the U.S. Central Command (Axios, 2020 January 8). There is American military base in Afghanistan, Iraq, Kuwait, Bahrain, Qatar, Oman and Saudi Arabia for the purpose of protecting its allied nations in the regions. Hegemon can even fund military exercise in form of a collective security organization under a signed treaty by the member countries such as NATO in anticipation of any eventuality such as threat from any aggressor against hegemon's allies. A good example is the current issue of Iran being accused of sponsoring Houthi in the on-going civil war in Yemen as well as attacking Saudi Arabia by proxy. The Kingdom of Saudi Arabia is one of the leading economically viable ally of US in the Middle East. Such a tension at regional level needs the role of a hegemon before escalation.

Similarly, the frequent nuclear testing perpetrated by the North Korea, a Socialist Republic creating tension, instability and insecurity among its neighbours: South Korea, and Japan who are long term allies of U.S. Hence, the hegemon cannot watch to see dictators undermining the world's peace. The idea of securing military bases by hegemon has a link to expansionism policy, to stand tall among nations while having her tentacles positioned in closer distance to defiant states. On the other hand, each independent community is expected to run the activities of her people and state without interference except where an elected political leader or military Head of State (authoritarian type of government) displays dictatorship tendency over its people, in such a situation, a hegemon could have a say, call for the practice of social justice and practice of full democracy.

Since the thirteen centuries in (Table: 1 above), history witnessed some nation states such as Portugal, Holland, Britain and host of others that activated their leadership reasoning. They channeled their curiosity beyond their immediate locations and some even added more values to what they knew better or did better. Thereby, the need to develop relations to share ideas and resources where one country had advantage over others while those who had soft or hard power used it to bring others to submission in order to get from them what the global leadership pretenders lacked. Hence, the beginning of international relations and the establishment of the feelings of dominance after WWI. Similarly, the human natural feelings or perception to aspire for leadership position by forcefully controlling others with natural or man-made power led to the advent of hegemony.

Hegemon pretender may have identified the availability of some natural wealth such as Diamond, as in (Russia and Democratic Republic of Congo), Oil, as in (Venezuela with 300.9 billion barrel that worth $18 \%$ of world deposit, Saudi Arabia with 298 billion barrels worth 17\% including many other economically vibrant resources. The government of hegemon state may use the position to get the resources for economic empowerment of his own country, hence establishing economic relations through trade with countries having the resources. Such was the perception and intention of the colonialism in the 16th and 17th centuries. The hegemonic influence brought about the creation of IMF and World Bank including the introduction of American currency (Dollar) as the only mandatory international monetary measure of payment and foreign exchange in the aftermath of WWII. The hegemon, using it for manipulating payment of resources from the developing countries to control the world economy to its advantages and that of the advanced countries. All these and many other political and economic strategies have facilitated influences toward leadership control. Similarly, the Security Council where only five advanced nations constituted its membership, represents the only rubber stamp for all deliberations made by the General Assembly of 200 countries in the world to the 
INTERNATIONAL JOURNAL OF ACADEMIC RESEARCH IN PUBLIC POLICY AND GOVERNANCE

Vol. 7, No. 1, 2020, E-ISSN: 2312-4040 @ 2020 KWP

advantage of hegemony and other regional major powers. The inclination to lead and control the social, economic and political spheres was observed as an example of hegemonic aspiration adopted by Adolf Hitler that was coined as autocratic leader over the European terrain in 1933 or that of Josef Stalin with his committed crimes against inhumanity, the brutal dictator in the Kremlin (John, 1997). Though the area of power advantage of each aspiring hegemon may be different, yet all are of paramount importance for creating stable world order.

\section{Hegemonic Power: Theoretical Perspective}

The hegemonic theory, in a central idea which states that the stability of the International System requires a single dominant state to articulate and enforce the rules of interaction among the most important members of the system. However, for a state to assume the position of hegemon, it is required according to some studies that it must be capable to enforce the rules of the system. The will to lead and establish a hegemonic regime and be committed to a system which is perceived as mutually beneficial to the major states. Three attributes on which the hegemon capability rests as proposed by some of the theorists of hegemonic power are: a large growing economy, dominance in a leading technological or economic sector and political power that is backed up by projective military power (Jack, 2016). Theoretically, the United States of America is undoubtedly living within such disposition, while China if projected to assume hegemonic position may need to be clearly examined and evaluated prior to being suggested as a qualified pretender of hegemonic status in the current international system. The position of hegemony is not only accredited to a nation for being just powerful or economically vibrant; but such must unreservedly be capable to keep the global system in a perfect peace under one hegemonic leadership.

Lull (1996) posit that Hegemony is the power or dominance that one social group holds over others. However, Straubhaar (1991) in Lull refers to the hegemony as the "asymmetrical interdependence" of political-economic-cultural relations between and among nation-states as each nation has different size, shape, resources and other physical attributes. Hence, the differences between and among social classes within a nation. That differences, identified in the social class are not either accidental or natural hence, the differences are seen as power structured domineering factors used by those states who are custodians of such influences over those states who have not in the international relations. Nevertheless, Lull (1995) maintained his argument that hegemony is more than social power itself; it is rather, a method for gaining and maintaining power. Susan Strange (1923-1998), a British scholar perceived Hegemon as the ability of one party to affect outcomes in a way that their preferences take precedence over the preferences of other parties. Therefore, to say the United States is still a hegemon is tied into whether or not it has lost such power.

\section{Theorizing the Mechanism to make Hegemon}

James (1995) explains that Hegemony is an agreement by states who willingly accepts that they be governed by principles, rules and laws in which they have their belief for their best interest even if it is not true. Social consent is an effective and solemn means to rule and force. Hegemony is not a direct stimulation of thought or action, while Stuart Hall theorizes Hegemony as the strategy which the dominant class sets the limits- mental and structural within scope that the subordinate classes 'live' and make sense of their subordination in such a way as to sustain the dominance of those ruling over them" (1977: 333). However, Philip Elliott perceived it as the powerful effect of mass media with which it attracts their audience to believe the role of social factors and economic forces in delivering 
INTERNATIONAL JOURNAL OF ACADEMIC RESEARCH IN PUBLIC POLICY AND GOVERNANCE Vol. 7, No. 1, 2020, E-ISSN: 2312-4040 @ 2020 KWP

rhetoric concepts being labelled and evaluated to convince the society to submission (1974: 262). In the words of Gitlin, television advertisements for examples, encourages audiences to believe they represent markets instead of a public, as consumers rather than citizens (Gitlin, 1979: 255). Again, to Raymond Williams, hegemony, in its wide sense is [where] electoral politics and public opinion are significant factors on which social practice consent to certain dominant class needs (1976: 145).

Hegemon's strength and wealth are not necessarily the leverage but the success appeal of its ideology, the strength of its institutions, and the drawing power of its culture of mass consumptionwhat many scholars nowadays call "soft power". Straubhaar (1977) posits hegemony in form of differences that exist between and among social classes within a nation or the "asymmetrical interdependence" of political-economic-cultural relations between and among nation-states. However, to Hall (1985) hegemony is "dominance and subordination in a power structured relations as cited in (Lull, 1995). Many classical scholars and theory analysts have studied and identified hegemony as a means not only needed, but absolutely necessary to garner power for dominance. I coined hegemony as a strategy embarked upon by a nation to ascend to the world leadership position through the use of resources, while subjecting the rest countries of the world not only to coercion or submissiveness but also to heed the ideological standpoints of the hegemony pretender.

The success of these strategies provide the potential hegemony all that is needed to maintain great position while in control. For instance, the concept such as the freedom of speech, justice, human rights, and sense of inclusion portrayed the America exceptionalism. They are powerful sentiments accorded all immigrants from developing or authoritarian controlled states which eventually love in love with and chose United States of America as home. Study shows that culture and ideological legacy and the media portrayer of a state play a significant role in building hegemonic power for a pretender state. This is closer to the theory of international relations that includes the fields of economics, history and political science as complements. Hence, hegemony is a method for gaining and maintaining power over others because any power possession without practical and physical use in terms of being victorious over internal and external aggressors cannot be classified as potentially reliable. It seems the limitation of hegemonic power can only be measured or determined through implementation. That draws us to the realist theory of coercion over others to achieve national interest. 
INTERNATIONAL JOURNAL OF ACADEMIC RESEARCH IN PUBLIC POLICY AND GOVERNANCE Vol. 7, No. 1, 2020, E-ISSN: 2312-4040 @ 2020 KWP

\section{History of the Hegemons}

Table 1: Historical Record of Hegemonic Leadership

\begin{tabular}{|c|c|c|c|}
\hline Hegemony & $\begin{array}{c}\text { From Year- To } \\
\text { Year }\end{array}$ & Period & Basis \\
\hline Portugal & $1494-1580$ & $\begin{array}{l}\text { End of Italian Wars to } \\
\text { Spanish Invasion } \\
\text { Portugal }\end{array}$ & $\begin{array}{l}\text { Portugal's championed the on navigation } \\
\text { expedition. Spain aspired for hegemonic } \\
\text { position }\end{array}$ \\
\hline Holland & $1580-1688$ & $\begin{array}{l}1579 \text { Treaty of Utrecht } \\
\text { marks the foundation of } \\
\text { the Dutch Republic to } \\
\text { William of Orange's arrival } \\
\text { in England }\end{array}$ & $\begin{array}{l}\text { Dutch dominated and controlled credit and } \\
\text { money. England became Hegemonic } \\
\text { pretender }\end{array}$ \\
\hline Britain & $1688-1792$ & $\begin{array}{l}\text { (Glorious Revolution to } \\
\text { Napoleonic Wars) }\end{array}$ & $\begin{array}{l}\text { The British controlled industrialization of } \\
\text { textiles as well as the High Seas. During the } \\
\text { time, France was in line as Hegemonic } \\
\text { pretender }\end{array}$ \\
\hline Britain & $1815-1914$ & $\begin{array}{l}\text { (Congress of Vienna to } \\
\text { World War I) }\end{array}$ & $\begin{array}{l}\text { British keep on maintaining supremacy in } \\
\text { industrialization and dominance in railroads. } \\
\text { Germany was tipped as Hegemon pretender }\end{array}$ \\
\hline United States & $1945-1971$ & 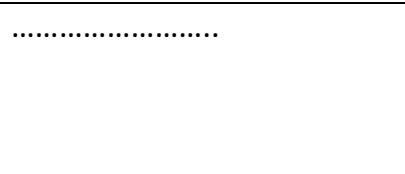 & $\begin{array}{l}\text { American discovered Petroleum processes } \\
\text { and maintained leadership on the Internal } \\
\text { Combustion Engine. The USSR was seen as } \\
\text { Hegemonic pretender. }\end{array}$ \\
\hline
\end{tabular}

Source: Vinnie, updated (2019). (Modified as table by the Researcher)

The theory of Hegemonic Stability according to the table: 1 above

In Table 1: Portugal was the first hegemon, the initiator of hegemonic power due to her ability to embark successfully on sea navigation and exploration that led to discovery of continents like Africa, Asia. Portuguese explorers managed to find the sea route to Asia in 1498, the opportunity it maintained to outcompete and nearly eliminate, the caravans' trade. Portugal managed the position for almost 100 years without competitors (Mueller, et al. 2017). Portugal lost the hegemonic power to the Dutch when the latter in 1596 managed the passage around the Cape of Good Hope, conquered most of the eastern Portuguese colonies but the Portuguese maintained their American and African colonies (like Brazil, Angola, and Mozambique). The British power became hegemonic leader based on the British industrialization of textiles, command of the High Seas as well the rail roads (Figure: 1 above). The United States is the last and the current hegemonic power that has been reigning since 1945 after the Second World War while the Soviet Union was a palpable contender as well as pretender hegemony. The Soviet embarked on the procurement and production of nuclear weaponry, short, middle and long range missile launchers including the spread of socialist ideologies to aspire for regional and global hegemonic leadership. 
INTERNATIONAL JOURNAL OF ACADEMIC RESEARCH IN PUBLIC POLICY AND GOVERNANCE Vol. 7, No. 1, 2020, E-ISSN: 2312-4040 @ 2020 KWP

\section{American Hegemonic Interest}

After the World War II, the American policy-makers envisioned deeply and quickly realized what the falling regional powers could possibly embark upon if left loose without containment. They also studied the aftermath of the war and the level of pathetic devastation. In a way to prevent and contain USSR, the United State quickly provided security guarantee with military aids to France. This incentive would have helped France to contain Germany in case she becomes an object of attack by Soviet Union if it eventually resuscitates her industrial sector (William, 1998) as cited in (Leffler, 2005). Consequently, Timothy (1981) explained that the North Atlantic Treaty was signed in 1949 out of the America's fears about Germany as well as their anxieties about Soviet Russia. This strategy had clearly revealed the hegemonic aspiration and interest of the U.S. to lead the world. Hegemonic responsibilities meant power balancing, strategic commitments, and military alliances. Hence, the need for America to be sensitive to the looming return of aggression from the Soviet Union, while pursuing the policy of containment to prevent the spread of communist ideology against democracy as well as staging alliance with many of the regions of the world through assurance of providing assistance and maintenance of peaceful sphere of all regions. However, the Soviet Union; a powerful Eastern bloc socialist political power born in the violent upheavals of the "Great October Revolution of 1917" competed as well as aggressively challenged the hegemonic leadership of the United State finally collapsed in December 26, 1991 (New York Times 1991 December 26). The process of competitiveness, internal disintegration, bankruptcy, hungry within the Union of Soviet Socialist Republics (USSR) reported may have led to fall including a number of proxy wars coined as "The Cold War". The fall of Soviet put an end to the era of many international affairs scholars referred to as Multipolar during the Cold War era in 1989. The collapse death of the Soviet Union strengthened America's favourable disposition and determination to embark on continuous dominance over the World and help it to reign as the only powerful nation without active challenger with either military, technological or economic power to maintain a stable unipolar system.

\section{The Attributes that make USA existing Hegemon?}

In the international political system today, the US remains the only regional power in the Western Hemisphere, dominating both Mexico in the South and Canada in the north; compared to major powers in Europe with two or more big powers like Germany, France, Britain and Russia. And in the Asia continent, China equally has peer competitors like India, Japan and North Korea. In establishing this fact, it is unequivocal that Washington remains the most influential among other powers for its good relations with most of the international organizations such as the United Nations, International Monetary Fund, World Bank, World Trade Organization and many others. The US played a leading role as the largest financier of institutions annually. The U.S. remains the major financial contributor to the U.N. system, providing $22 \%$ of the U.N. regular budget and $28.43 \%$ of U.N. peacekeeping budgets (Congressional Research Service, 2018 April 25). The US paid US\$10 billion to the United nations in 2017 representing roughly one-fifth of UN budget (Quartz, 2019 September 24). The report explained further that the first top 10 of 193 UN member countries contributed $68.89 \%$ of the total UN contribution. However, 20 first countries contribute $83.78 \%$ of the fund while the other 173 countries contribute $16.22 \%$ only. The wider margin in the contribution of each member has indirectly shown those nations that are influential in benefiting the activities of the United Nations.

These marvelous financial support puts America at the top in decision making that concerns most global issues by using the World Bank to finance developing countries with low interest rates, 
addressing and supporting international development challenges to save economic collapse across the globe. Similarly, on the economic front, with the decline of the British after World War II as a global power, world power systematically shifted to the cabin of the US with the collapse of the British pounds as it (Britain) suffered a colossal economic loss in the war period. This is to say that for any state to survive and lead world as a hegemon, it must possess the power to control and influence the world economy.

Many assumptions have been questioned, particularly in light of the increased internationalization of the US economy. The business sector is no longer viewed in an exclusively domestic context. The economy of the United States is often tied to the economies of other nations. In the Asia-Pacific, the US remains a leading power for decades through trade and partnership with Japan, South Korea. The influence offered her the ability to benefit from the economic activities of the region after the Cold War. The United States offered a diplomatic contact to China so as to encourage her to become liberal and to streamline its own domestic prosperity and align with other states to champion international order.

Indeed, the end of the Cold War in the early 1990s and the collapse of the Soviet Union after the resignation of its leader Mikhail S. Gorbachev on August 29, 1991 at 7:32 pm to make a way for Commonwealth of Independent States (The New York Times, 1991) solidified US leadership on the world stage. This links to the fact that the key challenger against the U.S. (The Soviet Union) is dead after 74 years (1917-1991) of its struggle as a major power. Soviet Union's exit from the world leadership stage made the world politics to experience a kind of unprecedented struggle among the world major powers. Therefore, the world became a multipolar with the rise of other actors like China, Japan and others. During this period, the U.S. managed to dribble round to acquire economic buoyancy, by leading the world affairs with her newly fashioned international economic system benchmarked on a petro-dollar market system with her allies in the gulf region. However, as the world order entered a new dynamic process with the rise of China, the struggle for the balance of power resurfaced, paving the way for more competitors and a new distribution of power (Franziska, 2018). Though, the U.S. has used the strength of its dollar to a considerable extent to intimidate world economy at the expense of other states in Europe, Asia, Latin America, and Africa, that strategy facilitated international cooperation and provide a congenial opportunity for the exercise of American leadership. The United States projected power across Eurasia, creating a liberal economic order with openness that serves as counterweights against rival major powers and hegemonic projects (Ikenberry, 2014). The manifestation was reiterated when President Trump said while presenting before the UN General Assembly in September 2019 that:

"Our economy is the envy of the world. Perhaps the greatest
Economy we have had in the history of our country".

Donald Trump, September 2019

The Figure 1a: below shows the US economic performance with 3.1\% growth for the first quarter, but this slowed down to $2.1 \%$ in the second quarter (which ended in June 2019). This is significantly less than the 5.5\% achieved in the second quarter of 2014 during the Obama presidency. Similarly, Bloomberg argued that there were times in the 1950s and 1960s when the US GDP growth was even 
higher than what President Trump was claiming to be the best economy America has had in the history of the nation. Along the same issue, Megan Black, a History expert at the London School of Economics gave a counter-argument that Trump's claims are suspect when comparing the health of the American economy based on the GDP to national economic boom of the post-War years. In spite of the fact that Trump claimed that six million American are on the pay roll in the last three years, the index of US economy's data is reported to be volatile as a result of trade confrontation between America and China. The graph in figure 1a, clearly indicates that the economy in the early 2019, the first quarter of the year, performed poorly compared to the last quarter of 2018. Consequently, the trade war poses a serious implication to the economy. In the figure 1b, Dow Jones performed creditably with upward trends in US stock exchange and that is positive to the economy of Unites States, but other sectors would need to be addressed to maintain all round balance in the sectors of the economy (Bloomberg, 2019 September).

\section{Figure: 1a United States of American Economic Growth}

\section{US economic growth}

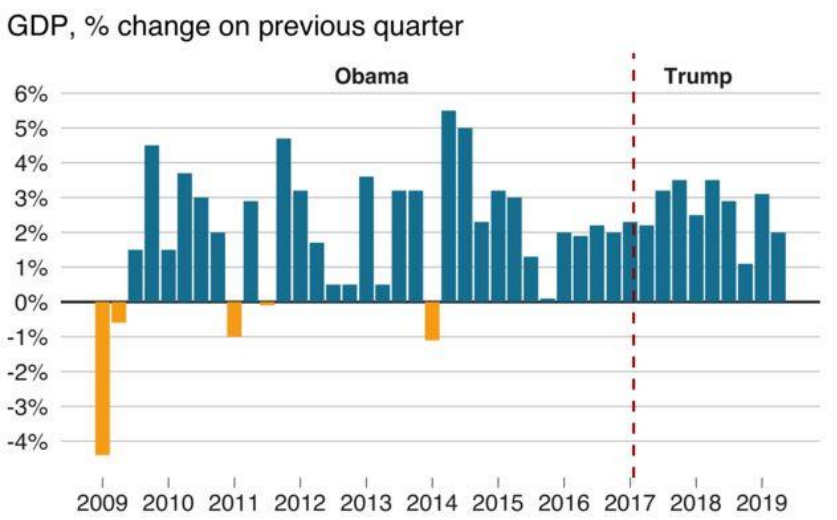

Note: Seasonally adjusted annual rate

Source: U.S. Bureau of Economic Analysis

(BBC Reality Check Team, February 17, 2020). Retrieved from https://www.bbc.com/ news /world-45827430

The figure $1 \mathrm{~b}$ below shows the economic performance of the United States of America with more indication to justify the encouraging performance of the most famous stock market barometer, the Dow Jones Industrial Average (DJIA). The Dow is price weighted and tracks a basket of 30 of the largest and most influential public companies in the stock market on the New York Stock Exchange (NYSE) and the NASDAQ. President Trump was laying claim to Dow's success as part of his administration's economic achievement, while delivering a speech before the UN General Assembly on the American state of economy. In essence, it is an indication that the public companies are economically viable under Trump. 
INTERNATIONAL JOURNAL OF ACADEMIC RESEARCH IN PUBLIC POLICY AND GOVERNANCE Vol. 7, No. 1, 2020, E-ISSN: 2312-4040 @ 2020 KWP

Figure: $1 b$ US Economy under Trump

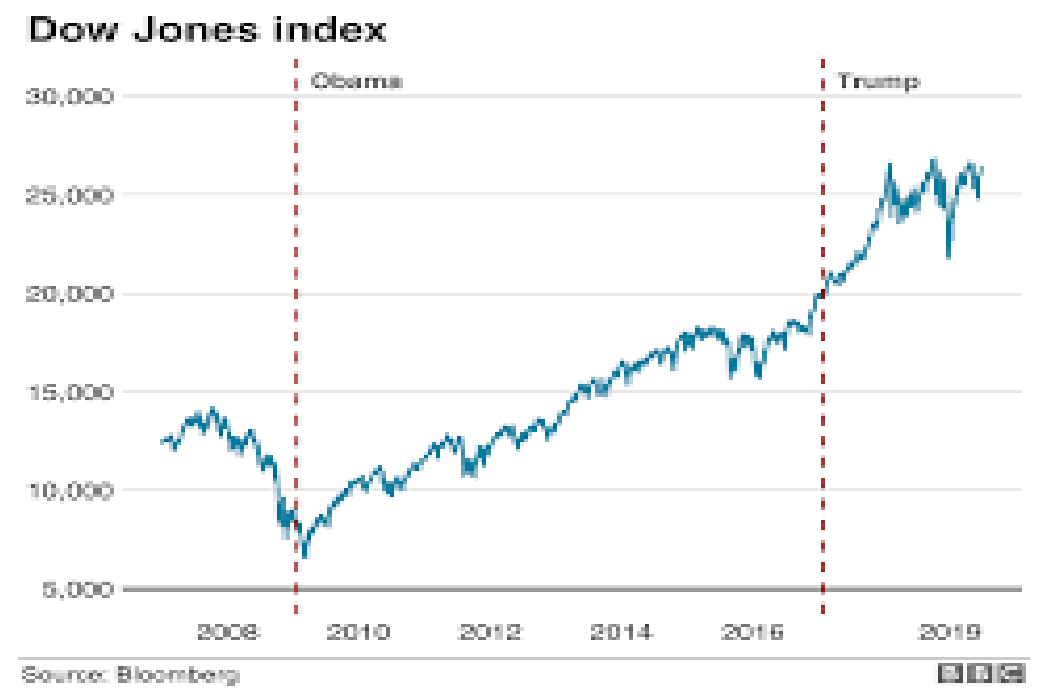

Bloomberg: In (BBC Reality Check Team, February 17 2020). Retrieved from https://www.bbc.com/ news /world45827430

Although, there has been a series of consistent debate in anticipation of the collapse of such financial institution, International Monetary Fund with which the U.S. struggles to maintain the status quo after the economic downturn in 2008. This model of global order creates a form of asymmetrical cooperation or interdependence in the international system structured within the control of the U.S. since the aftermath of Cold war (Mearsheimer, 2015; Keohane, 1984). 
INTERNATIONAL JOURNAL OF ACADEMIC RESEARCH IN PUBLIC POLICY AND GOVERNANCE Vol. 7, No. 1, 2020, E-ISSN: 2312-4040 @ 2020 KWP

Figure 2: The America's National Debts 2019

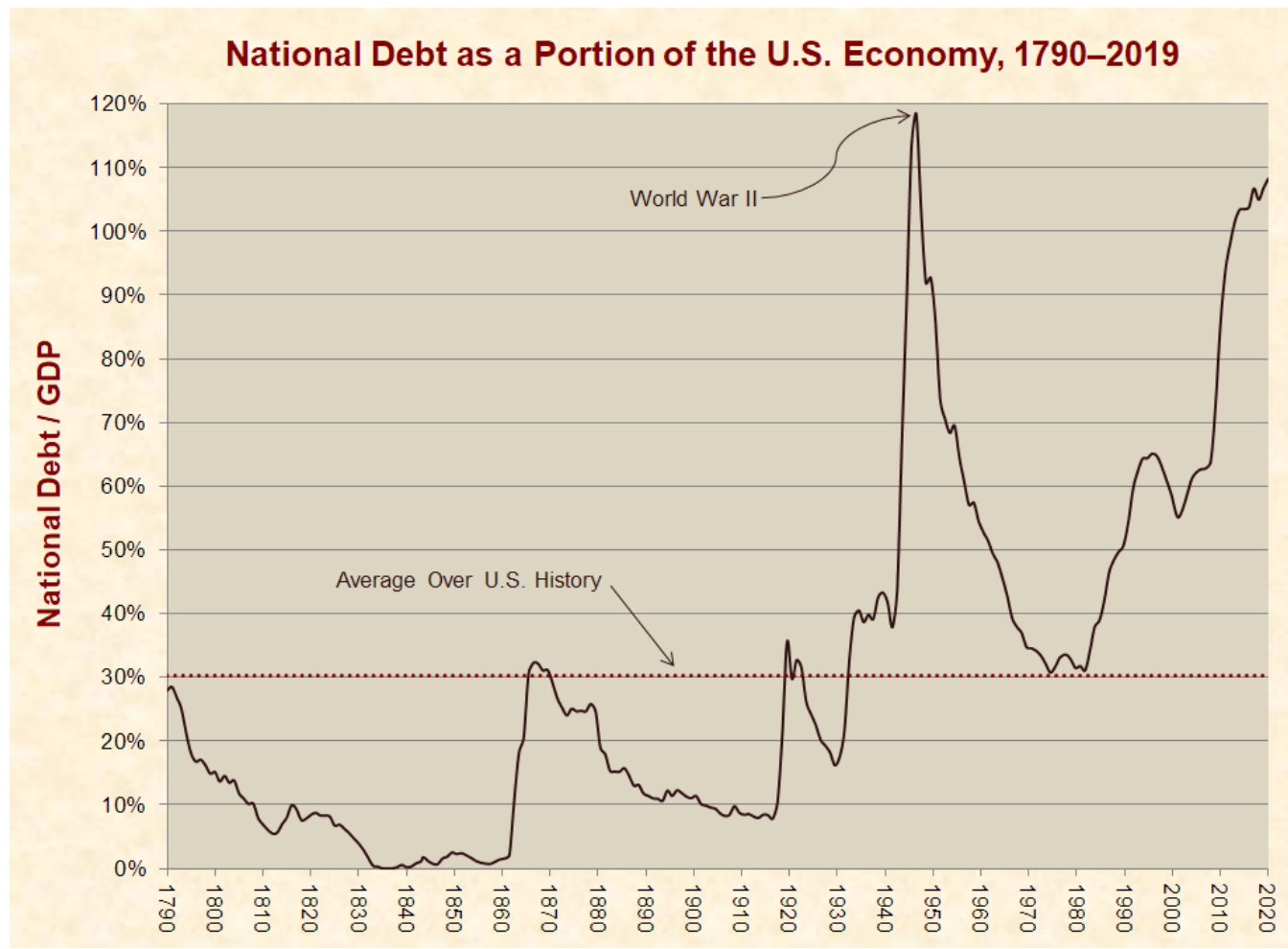

Source: Just Facts, (2020). https://www.justfacts.com/nationaldebt.asp

In reference to figure 3: Just facts (2020) revealed that as of February 3, 2020, the official debt of the United States government is US\$23.2 trillion, more precisely, US\$23,205,880,808,458. The report mentioned further that at the close of 2019, the size of the national debt relative to the U.S. economy was at 3.6 times higher than its average over the US history. However, the report reiterates that debt held by the public is the largest explicit liability of the federal government. Similarly, another report indicated that approximately $29 \%$ of the debt held by the public was owned by foreigners. From our study, it is discovered that the American debt was at its pick 106\% of the GDP in 1946 shortly after the WWII (concord coalition.org). Such a huge debt profile may have emanated from America's commitment and unabated pursuit to persistently maintaining the hegemonic power. Concord Coalition Organization therefore observes and suggests that:

The national debt is already quite high by historical standards... because of the aging of the population and rising health care cost and if not controlled, the debt could rise even more with additional spending programs or tax cuts without "paying" for them through other budgetary changes.

(The Concord Coalition Organization 2019 October 3)

Away from Europe and Asia, the Middle East has been a major focus of the US foreign policy most notably since the aftermath of the 9/11 event. The U.S. has both economic, political and strategic interest in the region. Her interest in the region includes the strategic access to oil in the gulf, maintaining her military bases, protecting and supporting Israel sovereignty, defending proxy states 
INTERNATIONAL JOURNAL OF ACADEMIC RESEARCH IN PUBLIC POLICY AND GOVERNANCE Vol. 7, No. 1, 2020, E-ISSN: 2312-4040 @ $2020 \mathrm{KWP}$

and friendly regimes (Atallah, 2017) with a very strong bilateral ties still in the Middle East (Jim, 2018). Although, in recent years, the U.S. influence in the region is practically declining. It is understood that it no longer depends on the region's oil supplies which emanated from the manifestation of the global oil market (Jeff et al. 2018). Be that as it may, the US still remains a dominating and influencing force in the Middle East.

Significantly, the U.S. has been able to maintain a steady diplomatic alliance with countries like Saudi Arabia, United Arab Emirates, with the provision of defense weapons exponentially. For more than two decades, the Corps of Engineers has been critically involved in helping the Saudi Government with military construction and other massive projects like the new military cities in the desert, military academies and port facilities. The list totaling about $\$ 20$ billion and $\$ 25$ billion over the next 10 years (US Congress: Committee on Foreign Affairs).

Needlessness to say, as the world is moving toward a global shift, which is to reconfigure the international order and the dynamics of global affairs as a result of political interconnectedness, economies, cultural and knowledge globalization, and the sudden rise of China (Franzisko, 2018) such alliance is undergoing an inconsistent position.

\section{American Dominance in a Leading Technological or Economic Sector}

The US is undoubtedly one of the leading nation in terms of advanced sophisticated technological weapons. In addition, Washington is known for its drive and competitive spirit in order to forge ahead of other developed nations technologically and economically. However, during the Cold War period which unleashed U.S. nuclear capacity to bomb the Hiroshima and Nagasaki during the WWII, setting the pace for other superpowers like the former Soviet Union to join the league in possessing nuclear arms, successfully tested at Semipalatinsk, Kazakhstan on August 29, 1949 (History Editor, 2010 February 9). Indeed, this incidence transformed the dynamics of international politics in term of security and the perception of other states in their relations with the U.S. Exponentially, such strategy became manifest with his strong rapprochement with Japan by establishing a long lasting strategic alliance. But however, failed with other states as it chased them into the race of a nuclear arm for self-defense and balance of power. In light of the above, it is critical to examine the composition of U.S. nuclear facilities and its power to project force as a leading hegemon.

All US nuclear weapon is under the control of both the Department of Energy (DOE) and the Department of Defense (DOD). The National Nuclear Security Administration (NNSA) is the body responsible for overseeing research and development, testing, maintaining, acquisition programs and the sustenance of nuclear war heads. However, the nuclear weapons complex described by NNSA as the Nuclear Security Enterprise is basically composed of nine government owned contractors. They operate in seven different states with a Tennessee Valley Authority (TVA) nuclear reactor which is used to create Tritium for nuclear weapons. The complex is known to have been created beginning with the Manhattan Engineer District in 1942, which later grew in size in the period of the Cold War, prior to developing into the present configuration during the 1990s. Equipment at the present nine centers comprise of five component fabrication, three laboratories, a geologic waste repository, one disassembly and assemble site, and one testing device which performs research, though erstwhile was a location for U.S. underground testing of nuclear device (Amy \& James, 2018).

Despite this mountain of nuclear achievement, the US under the Trump administration has increased its budget for FY2019 to fund NNSA weapons activities with $\$ 11.02$ billion, compared to the budget 
INTERNATIONAL JOURNAL OF ACADEMIC RESEARCH IN PUBLIC POLICY AND GOVERNANCE Vol. 7, No. 1, 2020, E-ISSN: 2312-4040 ๔ 2020 KWP

of the Obama's administration US\$7 billion in FY2011 for the maintenance of nuclear stockpile and complex. This expensive nuclear procurement is an extension of U.S. leadership in military might.

\section{American Political Power Backed up by Projective Military Power}

By far, NATO remained one of the strongest military alliance in the World since its creation in 1949 (Richard, 2016) with US being one of its leading member nations. This alliance was formed after the Cold War to counter-balance, deter and contain a possible attack from Russia with a fierce response. As observed by (Glenn \& Conor, 2018) its primary goal is to pursue or deter Russia from having a significant and independent role to play in Europe. Secondly, to ascertain Russia as being no threat which is holistically termed as 'deterrence cooperation dichotomy' in NATO-Russia relations. Therefore, NATO is considered to be an insurance policy for its members against a possible war with Russia. With this in place, Washington has been able to protect itself and her European allies from a future threat or attack from Russia in the Western hemisphere. Thus, balancing the envisaged danger. Indeed, despite appearance as unwilling and unable and much skepticism hovering the sustenance of this alliance with Europe economic sluggishness, and disinterest in using force, he alliance largely remains of great importance for the security of the U.S. As she incessantly commits itself to a US-Euro collaboration to sustain her security being the most important on the globe for dealing with troubling security hazard (John, 2015). All is an effort to maintaining the lead as a global power. Strategically and geo-politically, the U.S. remains an influential power in East Asia. This success is attributed to the promulgation of her liberal ideas power and interest. This has been a fundamental grand strategy of the U.S. to maintain a critical and strategic relationship with East Asia in an effort to shape and maintain the rise of China. More importantly, to ensure that the rise of China does not transform the region into an illiberal entity.

The establishment of NATO is undoubtedly a strategic cooperative alliance. Its fundamental strategy was for the U.S. to remain cling with other democracies in Europe, East-Asia. While US-Japan alliance was a major paradigm of maintaining similar relations with non-communist states to formulate a world security and avoid a game of strategic rivalries among the leading democratic powers. It also eschews the dangers of power politics. The strategy helps liberal international system thereby retaining reliable and dynamic power in the American institutions with vast integration with East-Asia and Europe (Ikenberry, 2014).

\section{China Economic, Technological Development and International Relations}

Though, China has tremendously improved on its political, economic, and social performance including the human rights records to stand out as a major power, all things being equal. As a member of National Security Council (world major powers), China has preferences in the UN Security Council. One of these is that, she can veto any implementation agenda of the council on any global issues just like any other member of the council. For instance, China including Russia vetoed the proposed United Nation sanction on Syria in 2017 over the use of Chemical weapon against its people in 2014 and 2015 after the UN completed and submitted its investigation report (BBC, 2017). Chinese reaction could have attributed to its interest to prevent further escalation of the war as well as to prevent increase of burden on humanity that may demand further humanitarian assistance which may not be met on time and thus increase sufferings. Other issues could be on environment, nuclear issues, security issues or any decision about regional issues. She plays important roles in providing economic aids and financial assistance to many developing countries not only in its region where it 
INTERNATIONAL JOURNAL OF ACADEMIC RESEARCH IN PUBLIC POLICY AND GOVERNANCE Vol. 7, No. 1, 2020, E-ISSN: 2312-4040 @ 2020 KWP

enjoys regional leadership but, it has also penetrated other continents. She builds potential hegemonic ability by providing some developing nations in Asia, Middle East and Africa with economic and technological assistances, building capital projects and improving trade relations with them. A strategy to improve diplomatic and economic relations on bilateral agreements in order to secure them as its strong allies and to empower them economically.

Clearly, it is an undisputable sign that China is pursuing an agenda of assuming a position of great power, considering the recent Chinese occupation of the South China Sea. An act of violation which some intellectuals across the globe regarded as encroachment of the sovereign territorial space of other countries that have legitimate rights of ownership to the disputed areas. China's human rights record seems improving after the brutal event at Tiananmen Square in 1989, its less aggressive control on Taiwan with semi autonomy, the political system of one country two systems in Hong Kong. However, the China's grip on Tibet, Macao is a form of strategic repression that challenged their fundamental human rights. The Tibet freedom movement are persistently repressed with violent attacks while China presents propaganda on media to dignify her communist power. All these, apart from China's aggressive economic development are strong indications that China is nursing a determined agenda as a means to put itself on a pedestal of World Hegemon. The only point that remains unclear, which is the objective of the research in context is whether China is pursuing to be the only major power (hegemony) or considers herself a power among other World powers (Multipolar) to control global affairs. The study investigates the intention of China to rise to the position of hegemon.

\section{China's Prospect and Challenges to Become a Hegemonic Pretender}

Evaluating the prospect of China as a pretender hegemon, it is essential to critically observe from the perspective of both military and economic strength simultaneously. An observation in this sector is what experts regarded as inevitable sectors that are imperative before a state could lay claim to the aspiration of a global power. The global order has already been redefined by the rise of China at least as a stable regional power in East Asia due to the result of her Military and economic progressive build-up (Ikenberry, 2014). China embarks on active and meaningful foreign policy that pursues a symbiotic fashion of relationship with the neighbouring states and other countries. The condition of China's economy since the early 1980s has been on impressive rise with massive result. Many experts are optimistic about a continuous and expanding strand similar to the previous years in future decades. If possible, China, with its massive population potential, could translate her soft-power to a formidable military might, making her a military powerhouse is likely a reality (John, 2013).

In the light of the above, China has continued to rise and spread its economic potential by embracing capitalism and globalization. An idea from the Mao's Great leap upward toward the late 1950s and early 1960s in order to catch up with the evolving world. In her economic pursuit, China has been able to establish a strong bilateral tie with Russia and South-East Asia and further expand its interest into the core of Africa and the Arctic. China has been able to advance her economic ties in Africa through trade as it continuously grows from \$10 billion to US\$200 billion between 2000 and 2014 . China has steadily grown and maintained its presence in the Arctic over the past 30 years, due to the climate change which has paved the way for the possibility of northern trade routes and enabling access to marine resources. It equally holds the largest non-nuclear icebreaker in the world (Xue long 
INTERNATIONAL JOURNAL OF ACADEMIC RESEARCH IN PUBLIC POLICY AND GOVERNANCE Vol. 7, No. 1, 2020, E-ISSN: 2312-4040 ๔ 2020 KWP

'Snow Dragon') with an expanding interest in commercial shipping and securing new energy supplies (Peter \& Shahin, 2015).

Figure 3: Rate of China's GDP Growth

\begin{tabular}{|l|l|ll|}
\hline YEAR & GDP GROWTH Y/Y (REALIZED) & $\begin{array}{l}\text { FISCAL DEFICIT } \\
\text { (REALIZED) } \\
\text { CENTRAL GOVT REALIZED }\end{array}$ & INFLATION \\
\hline 2016 & Between 6.6-7\% (6.7\%) & $3 \%(2.9 \%)$ & $3 \%(2 \%)$ \\
2017 & Around 6.5 or slightly higher (6.8\%) & $3 \%(3 \%)$ & $3 \%(1.6 \%)$ \\
2018 & Around 6.5\% (6.6\%) & $2.6 \%$ & $3 \%(2.1 \%)$ \\
2019 & Between 6.5\% (6\%) & $2.8 \%$ & $3 \%$ \\
\hline
\end{tabular}

Source: China National Statistics Bureau

Figure 3: above shows that it is healthy with the China's economy when its Gross Domestic Products (GDP) rate maintained over $6 \%$ four consecutive years as shown in the figure above. The striking China's GDP growth rate was in 2016 at 6.5-7\%. From the table, Fiscal deficit maintains improvement of $0.4 \%$ in 2018, compared to the two previous years in 2016 and 2017, while fluctuating negatively in 2019 with a difference of $0.2 \%$. The inflation rate of $3 \%$ is kept under control and seen to be better. The stability is under control and that is good for the economy.

The amount of debt that the China is currently struggling with was identified as an amount that represents U.S. external debt in the year 1900 of its economic history. As at 2019, China GDP growth rate is still between $6.5 \%$ and 6\%. South China Morning Post (2019) reports that Institute of International Finance shows China is indebted to the tune of over US\$40 trillion, this is estimated to be greater than (300\% of its economy), and equally interpreted to about $15 \%$ of the world total debts.

According to Shujie (2007), the Chinese Government has been able to reduce poverty and inequality, improve her economic growth, survived the problems of energy and material shortage, and the condition of her natural environment which stands to be positive for domestic stability. Also, Shujie envisaged that China will overtake Japan by 2017 which she already did looking at her current GDP rate and international recognition compared to the latter and still has the potential to relatively repeat the same when paired with the United States by 2037. During 1978-2006, China achieved an average annual growth of 9.6\% in real GDP. China's GDP in 2006 was \$10.5 trillion, compared with \$12.9 trillion for the U.S., US\$13.0 trillion for the EU, US\$4.1 trillion for Japan, US\$3.9 trillion for India, US\$2.6 trillion for Germany and US\$1.9 trillion for the UK. China is the third largest economic bloc after the EU and the US and the second largest economy after the U.S. Furthermore, with the dramatic pace of China's growth without emphasis, is a significant potential to become world leader in science and technology notably with the introduction of the $5 \mathrm{G}$ network by Huwaei; one of China's leading technology company. China is in possession of the world most advanced nuclear, computer, space, and energy, military, medical and biological technologies (Shujie, 2007: p.1).

The OECD reports that China has become a world leading giant in some service endeavours, notable among them are internet based, digitalized related trades such as e-commerce, online payments and car hailing services. China's e-commerce market was measured to be twice that of US in 2016 while 
INTERNATIONAL JOURNAL OF ACADEMIC RESEARCH IN PUBLIC POLICY AND GOVERNANCE Vol. 7, No. 1, 2020, E-ISSN: 2312-4040 @ 2020 KWP

a quarter of it is under shopping via online, and the rest is on business-to-business services (CNNIC, 2018b).

China's shared economy performed at 6\% of GDP in 2017, that is less to the assumed $10 \%$ in 2020 and $20 \%$ in 2025. Financing is the key area, while daily services, knowledge and skills, transport are identified, and followed by production capacity, accommodation and medical services.

(OECD, 2018)

It is important to acknowledge the impact the private enterprises contribute to shape and develop Chinese economy.

In 2017, it was found that sharing economy had crated $10 \%$ of new employment in which (1.3 million) was in the sharing economy and employed 7.2 million people. Didi Chuxing's online car hailing company employed nearly 4 million laid-off workers in addition to 1.3 million unemployed and 1.8 million who were former soldiers. Regulations and implementation are the required condition for effective sharing economy.

(OECD, 2018)

Woetzel et al. (2019) reports that China's technology value chains are highly integrated globally. In its analysis 81 technologies in 11 categories, the report found that more than 90 percent of technologies used in China are strictly invented with global standards. Furthermore, it suggests that though, Chinese players have grown rapidly but they still import critical components such as reduction gears (robotics), power electronics (electric vehicles), and equipment (semiconductors). Chinese imports now account for 16 percent of gross output in Australia, compared with just 4 percent in the previous time. Iron ore alone accounts for 48 percent of Australia's exports to China (minerals and metals in total represent 84 percent of exports), and 21 percent of Australia's mining and quarrying output is exported to China. China's ICT imports in 2017 totaled US\$528 billion, while its exports reached US\$781 billion. Competition from Chinese firms is strong, as the quality of domestic hardware, software, and services has continued to improve (export.gov Jul 30, 2019). Furthermore, the report mentioned that the Semiconductor Industry Association (SIA), China represents 50\% (\$168 billion) of the US\$336 billion global semiconductor market.

\section{America's weaknesses as Global Hegemonic Power}

The economic sector of the U.S. is persistently on downward slope in respect to previous years in history. Unemployment has become problematic for many years now while improvement is dwindling with no certain solution. As hegemon, US has not been able to control the global politics without series of military engagements that have tremendous toll on its economic preferences in Iraq, Iran, Afghanistan, Yemen and North Korea since 1989 after the Cold war. The recent challenges emanated from China were based on Trade issues between U.S. and China as U.S. proposed $25 \%$ trade tariff on Steel while China, after unsuccessful negotiation came up with counter measure to increase trade tariff on more than 300 items of American products exported to China. 
INTERNATIONAL JOURNAL OF ACADEMIC RESEARCH IN PUBLIC POLICY AND GOVERNANCE Vol. 7, No. 1, 2020, E-ISSN: 2312-4040 @ 2020 KWP

As at Jul 30, 2019 the U.S. debt was US\$22 trillion as of February 11, 2019. How much the United States owes China is not the most important question but how will the hegemonic nation overcome its dwindling economic power. However, it is a fact that the Social Security Trust Fund, such as the retirement, health and education bills owned most of the national debt. If the policymakers fail to reduce the national debts, budget deficits, increase the foreign reserve and taxes as well as employment, government spending would continue on the high trends and the outcome would lead to economic recession that may have serious impact on the world economic progress. For instance, Neta (2018) writes that America has appropriated and is obligated to spend an estimated US\$5.9 trillion on the war on terror through fiscal year 2019. Trade war with China is another cold war that does no one any good if each of the two world economic giants insist to engage on the trade war.

President trump administration increased tariffs on another US\$125 billion worth of Chinese imports while China responded by issuing on additional US\$75 billion worth of American goods (Foreign Affairs, 2019). To some experts, the trade war was regarded as the wrong way for America to compete with china. The inability of USA to decisively attack and rightly condemn Khashoggi's murder, a Saudi Arabian journalist that was clearly found to have been murdered inside the Saudi Arabian embassy in Turkey for criticizing the State on human rights abuses. Some of these abuses include the upholding of capital punishment, lack of freedom of expression, embargo on rights of the women to drive automobiles in the country and more. America's justification for not taken stern disapproval smeared the US integrity as a supposed fair world's hegemon that must uphold the fundamental principle of justice. The U.S.'s flagrant rejection of the binding treaty on Iranian nuclear procurement by the members of the Security Council after inspection and the restriction that Iran would not use its nuclear reactor for manufacturing of Nuclear Weapons is a global concern. America's withdrawal under president Trump from supporting and financing reduction of carbon emission policy initiative that causes the global warming is another U.S.'s backward step. Trump's series of racial discriminatory immigration policies including the America's unilateral approval of Jerusalem as the capital of Israel as well as many controversial policies that outlawed people's benefits are some identified challenges against the U.S. as hegemony of the current time.

\section{Finding and Analysis}

The study investigates and provides answer to the question: Can China rise to the position of the world most powerful nation: Challenges and prospect? Some Chinese nationals argue that "China has many poor people in the country in terms of well-being. The gap between the rich and the poor is huge. The Chinese people you see abroad are $1 \%$ of the 1.4 billion people." This was a critic of Chinese origin in an online comment under a publication that praises the Chinese over the manufactured longest-distance-fast-train that supplies about 200 containers to the heart of Europe. The refusal of China to respect human rights by continual persecution of the people of Tibet, and systematic genocidal attempt on its $10 \%$ Muslim community in China are of great concern to vote China as an epitome of hegemonic power as those autocratic traditions and motives present her as intolerant for freedom of speech, religion and human rights. John Fisher, Geneva Director at Human Right Watch said that "Twenty-two states have called China to task for its horrific treatment of Muslims in Xinjiang," (human Right Watch, 2019). The reaction is not in line with United Nation's Article ---- on human rights violation. The United States has been living with the Black Americans since the abolition of the Slave trades and many people of Caribbean Island, Mexico have become rightful citizens of 
INTERNATIONAL JOURNAL OF ACADEMIC RESEARCH IN PUBLIC POLICY AND GOVERNANCE Vol. 7, No. 1, 2020, E-ISSN: 2312-4040 @ 2020 KWP

America despite diplomatic rift with countries like Cuba, Venezuela, Nicaragua and few others while followers of religions are not victimized in USA.

Taiwan remains a segregated Island within the territorial sovereign land of China. The community is trying to gain autonomous power to become independent nation which China's Central authority has not been acknowledged or approved. The foreign policy of Taiwan with America is a great concern as Taiwan's militarism may be a motive to demand for independence while the mainland china found its secession unacceptable. The bilateral trade between China and Taiwan in 2014 was at upward trend of US\$198.31 billion, comparing to US\$8 billion valued in 1991 while U.S. had sold arms valued more than US\$46 billion since 1990 to Taiwan, and this in part, had led to US/China disagreement (Albert, 2016). In the case of another region under Chinese sovereign land is the Island of Hong Kong, it was a colony of the British for over 150 years and was later returned to the authority of China. The resolute attempt of Taiwan to reject status quo is confrontational to China hence; China is not in support of Taiwan/U.S. relationship especially on transaction of Arms and Ammunition to Taiwan. Similarly, the Hong Kong has been in protest against the dominance of the Mainland China on its political landscape.

Hong Kong is a city located off the southern coast of China's Guangdong Province. More than $90 \%$ of Hong Kong's population is ethnically Chinese. The Congressional Research Service (2019) explains that the first language of the vast majority is Cantonese. It is a variety of Chinese but different from what is spoken in most of China. In part because of its different language and long history as a British colony (1842 to 1997), the people of Hong Kong ("Hong Kongers") have a cultural and social identity distinct from that of Mainland China. China's interference in the governance of Hong Kong's political and economic autonomy, civil liberties, and rule of law threatens to undermine the city's economic prosperity and distinctive culture (Congressional Research Service, 2019). The same problem the people of Tibet faced in the hard-handed Chinese authorities in terms of inability to determine their independent life as they are dominated by the Mainland China. The on-going tension between China and U.S. and the South and Southeast Asian countries over the Chinese occupation of South China Sea has also caused diplomatic row between China and U.S. and other South Asian and South East Asian countries who claimed that China violates their sovereign rights. All these autocratic leadership tendencies and the recent trade war with US are pointing to the inclination of hegemonic power pursuant by China.

The study investigates and provides answer to the question: Can China rise to the position of the world most powerful nation? What are the challenges and the prospects toward such assumptions?

The answers to the above question come from the following findings: Some commentators could not trust China would not pursue hegemony or expansionism in the future irrespective of any assurance presented from any quarter. Referring to her 2.18 million active military personnel with almost $38 \%$ more than that of US army of about 1.4 million (Erin, 2020). China's use of military power, such as its aggressive action along the border with Korea and Vietnam. However, it shows remorse to convince the world of her innocence, as it has been notable for cautious, defensive and inward-looking national security posture. The Chinese huge population size, the military training to the sizeable segment of the population and the training on the use of technology. The leadership culture inherited from her historical dynasty portray her a formidable challenger to the United States of America on hegemony. 
INTERNATIONAL JOURNAL OF ACADEMIC RESEARCH IN PUBLIC POLICY AND GOVERNANCE Vol. 7, No. 1, 2020, E-ISSN: 2312-4040 @ 2020 KWP

The emergence of China as a potential Economic power across the globe now, is a seriously rekindled challenge to the dominant economic status of the United States. The economic improvement and development of China in the recent time with sporadic increase in its GDP, currency value, financial capability, economic alliance and assistance provided to African nations and other allies are clear signals toward pursuance of hegemonic power. Chinese scientific and technological innovations and improvement in modification on the currently procured technologies and aggressive improvement in education in all sector and ability to provide food security for its teeming populations are clear signs of global power outlook. The recent flexing of muscles to claim the ownership of South East Asian sea and other identified influences have motivated scholars and international affairs analysts to introduce China as the future hegemonic pretender around the globe.

The trade war between China and United States lately may expose the intention and limit at which any of the two world leading economies could employ their readymade resources to resist trade challenges that could portray their ability to hold on to economic hegemony should each maintain resilience over the implementation of their trade policy. Autocratic leadership tendency of China over Hong Kong, Taiwan and Tibet including restriction of communication among people and the monitoring of communication contribute to China gradual buildup of hegemonic power.

\section{Recommendations}

United Nations through international Atomic Energy Agency (IAEA) should call on the major powers, highlight strict measures including those that have been put in place over time to restrict nuclear armament procurement in the name of competing for hegemonic power. Through this restriction, the safety of the entire world could be enhanced. The caution should carefully address the uncontrollable stockpile of the quantity and quality of the deadly long and short range nuclear missiles and various weaponry of mass destruction because of its devastating effects on human lives. China should be aware that the relationship between America and USSR was not normal until the Socialist Republic fell in 1991. Similarly, the authorities of the People Republic of China should adopt low-profile military build-up while forging ahead with every possible strategy to improving and building economic prospect. Any move by China towards building military power like Russia, North Korea, Iraq, Syria or Iran would send a wrong signal to the authorities of the U.S. to perceive China as hegemonic pretender. That is a red line that was crossed by those countries mentioned above which provoked confrontation between U.S. and each of those countries. As a result, China should not aggressively upgrade her military status for now if it does not want to jeopardize her global economic influence.

As for the United State of America, it is important for Washington, to stockpile a substantial amount of military hardware and safeguard economic capability while promoting the use of its soft power to keep on piloting the affairs of the global system as current hegemonic power. U.S. could revisit, reconstruct and renew her strategic alliance with States like Iran in the Persian Gulf after the Joint Comprehensive Plan of Action (JCPOA); [the agreement on the Iranian nuclear program reached in Vienna on July 14, 2015, between Iran and the P5+1] and some countries such as Cuba and Venezuela in the South America. Similarly, as hegemon, America can establish a strategic negotiation with North Korea while maintaining a friendly, win-win economic relations with China for the benefit of international economic balance, global peace and security. Else, Russia and China may pick up the 
INTERNATIONAL JOURNAL OF ACADEMIC RESEARCH IN PUBLIC POLICY AND GOVERNANCE Vol. 7, No. 1, 2020, E-ISSN: 2312-4040 ๔ 2020 KWP

broken puzzle reframe and incorporate it into an alliance, a relation that could create a formidable force against Washington's interest in regional and global politics.

However, it may be too early for China to dangle more into military build-up as other major powers would also identify her as threat to global peace and that may call for collective security to check its military excesses. China would unavoidably lose focus on its economic power and other vital influences if confronted militarily by US and its allied nations if she allowed herself to be identified as threat to global peace.

\section{Conclusion}

The study explores the fundamental concepts and politics surrounding the criteria for being a hegemony in the world as whole. It highlights the previous hegemons along with their effort in discovery as well as in innovation that made them hegemons for a period of century or more. The United states became the last hegemon after the Britain and U.S. has been maintaining the preference till present time. The study reiterates that China's huge military investment on force projection capabilities in the Western Pacific, is possibly to enhance its global reach in the future. Recent People's Liberation Army (PLA) acquisitions (such as anti-carrier missile, stealth fighter, and aircraft carrier) and 2.18 million active army personnel may not go down well with the U.S. authorities. She may perceive the motive as China's military expansionist policy rather than a military build-up necessarily meant for regional protection. Other than that, excessive military procurement may unavoidably threaten U.S. military status and its allies in the Asian Pacific. For instance, US military stands at US\$609.8 billion while China's military stands at US\$228 billion respectively. In terms of economic strength, America is still the leading in prosperity with US\$20.49 trillion and US\$20.49 trillion if measured in terms of Purchasing Power Parity (PPP). China has been reported as the second leading world economy with values of US\$13.41trillion in nominal value and the world greatest with $\$ 25.27$ trillion in terms of Purchasing Power Parity (PPP) while Japan's Nominal GDP is $\$ 4.97$ trillion and US\$5.60 trillion if valued in (PPP) (IMF, 2019).

The Chinese government also aims to keep inflation under 3 per cent this year, the same cap she set for 2018. China's (GDP) grew 6.6 per cent in 2018, according to a report by the National Bureau of Statistics. Economically, USA is still the world leading economic and military power due to a number of factors discussed in the research including human rights freedom and the facts and figures presented in the literature, organizations' and governments' reports. However, considering the purchasing power parity (PPP), China is the most powerful economic giant but never in close rank with the United States of America when the economic value is measured in nominal scale.

The U.S.-China relationship in 2020s is expected to involve effort in regional, global public goods provision in the area of reducing greenhouse gas emission just as suggested by scholars. The notion that war is definite between China and the USA even a cold war not likely. However, assurance in the area of rivalry in cooperation between them as they would address solution to world issues together.

Policy Implication: The policy implication of this study is significant as it calls on policymakers to be mindful of their internal and foreign policies to build economic prospects while planning developmental policies inwardly for the well-being of the citizens and the progress of the state. The expansionist plans and aggression against foreign or neighbouring countries merely shift the focus of 
INTERNATIONAL JOURNAL OF ACADEMIC RESEARCH IN PUBLIC POLICY AND GOVERNANCE Vol. 7, No. 1, 2020, E-ISSN: 2312-4040 @ 2020 KWP

policy makers towards creating hegemonic power when probability to be one on the regional or global stage is the narrowest probability any developing nation should envisage. This study is an eye opener for political leaders who should concentrate on national interest. The decision-makers should see national economic prospect as prime alternative to hegemonic power.

Future Direction of the Study: New research should be based on investigating the area of intellectual property rights to find if China has truly infringed on the inventions and technology of the individuals, companies/organizations and the government in U.S. to achieve the knowledge that contributes to China's economic and technological development to become a potential economic giant.

Further studies may also investigate about the amazing varieties of scientific and technological research, inventions and other products of economic importance that were enlisted under the Chinese trademark. The study should find the initial inventors as the result would measure the capacity of China's claim towards attaining hegemonic power. If found otherwise, then, the North America's claim as the origin of such knowledge would add credit to her hegemonic preferences. Knowledge-based discoveries and power of inventions of a State should an indisputable part of the criteria for measuring hegemonic power.

\section{References}

American Organization of Historians and APActive. (n.d.). Cold War and Global Hegemony, 19451991. America on the World Stage: Retrieved November 8, 2019, from https://apcentral.collegeboard.org/series/america-on-the-world-stage/cold-war-and-globalhegemony-1945-1991

Atallah, S. (2017). United States Foreign Policy and the Middle East. Open Journal of Political Science, 7, 454-472.

Axios. (2020). Where U.S. Troops and Military Assets Are Deployed in the Middle East. Retrieved from www.axios.com/where-us-troops-and-military-assets-are-deployed-in-the-middle-east/

Reality Check Team. (2019). US economy under Trump: Is it the greatest in history? BBC News. Retrieved from https://www.bbc.com/news/world-45827430

Beeson, M. (2009). Hegemonic transition in East Asia? The dynamics of Chinese and American power. Review of International Studies, 35(1), 95-112.

Biegon, R. (2020). US Hegemony and the Trans-Pacific Partnership: Consensus, Crisis, and Common Sense. The Chinese Journal of International Politics, 13(1), 69-101.

Chemnick, J., \& Frank, T. (2020). Climate Change Once Again Left Out of Trump's Federal Budget: The administration's proposed spending for 2021 repeats previous calls for steep cuts to environmental programs. Retrieved April 20, 2020, from https://www.scientificamerican.com/article/climate-change-once-again-left-out-of-trumpsfederal-budget/

China's economy reached new heights': how the slowdown is being reported by Chinese state media. (2019). Retrieved November 24, 2019, from https://www.scmp.com/economy/chinaeconomy/article/2185437/chinas-economy-reached-new-heights-how-slowdown-beingreported 
INTERNATIONAL JOURNAL OF ACADEMIC RESEARCH IN PUBLIC POLICY AND GOVERNANCE Vol. 7, No. 1, 2020, E-ISSN: 2312-4040 ๔ 2020 KWP

Concord Coalition Organization. (2019). A Quarter Century of Policy leadership. Retrieved November 20, 2019, from https://www.concordcoalition.org/?gclid=CjwKCAiA_f3uBRAmEiwAzPua M7Y 3j7ADlo4XH384AEhguzjMvSxfkUP9_nWjd-cArdZQUdKRSW GrjRoCSpkQAvD_BwE\#id-13829.

Congressional Research Service. (2018). U.S. Funding to the United Nations System: Overview and Selected Policy Issues. Retrieved from https://fas.org/sgp/crs/row/R45206.

Covarubbias, J. A. (2003). The United States - Reluctant Sheriff or Potential Hegemon? American Diplomacy. Retrieved on March 10, 2020, from

Crawford, C. N. (2018). United States Budgetary Costs of the Post 9/11 Wars Through FY 2019: \$US5.9 Trillion Spend and Obligated. International and Public Affairs Watson Institute Brown University. Retrieved November 25, 2019, from http://watson.brown.edu»cow/pdf

Duffin, E. (2020). World's Largest Armies by Active Military Personnel 2020. Retrieved February 29, 2020, from http://www.statista.com/statistics/2644

Elliott, P. (1974). Uses and gratifications research: A critique and a sociological alternative. In J. G. Blumler and E. Katz (Eds.). The Uses of Mass Communications: Current Perspectives on Gratifications Research. Beverly Hills, CA: Sage.

Forbes. (2020). Why Did President Trump Request India for Hydroxychloroquine? Retrieved from https://www.forbes.com/sites/saibala/2020/04/13/why-did-president-trump-request-indiafor-hydroxychloroquine/\#1348b9b670bb

Foreign Affairs. (2019). The Unwinnable Tarde War: Everyone loses in the U.S.-Chinese Clash- but Especially Americans. Retrieved on November 282019 from http://www.foreign affairs.com/article/

Foreign Policy. (2020). Mask Diplomacy' a Boost for Taiwan: With U.S.-China relations showing scant improvement, Taiwan may bolster its global standing. Retrieved from https://foreignpolicy.com/2020/04/13/taiwan-coronavirus-pandemic-mask-soft-powerdiplomacy/

Franziska, B. (2018). Hegemony Revisited: A Conceptual Analysis of the Gramscian Concept of Hegemony in International Relations Theory. A thesis submitted for the Degree of Master of Science in Global Studies. Department of Political Science, Faculty of Social Sciences, Lund University.

Gaddis, J. L. (1997). We now know. Rethinking Cold War History.

Glenn, D., \& Conor, K. (2018). The offensive posture of NATO's missile defense system "Communist and Post-Communist Studies".

Goh, E. (2014). The Struggle for Order: Hegemony, Hierarchy and Transition in Post-Cold War East Asia. Oxford: Oxford University Press Publication. Retrieved March 16, 2020, from http://sdsc.bellschool.Anu. edu.au/experts-publications/publications/1831/struggle-orderhegemony-hierarchy-and-transition-post-cold

Gramsci, A. (1971). Selections from the Prison Notebooks. New York: International.

Hall, S. (1977). Culture, media, and the "ideological effect." In J. Curran, M. Gurevitch, and]. Woollacott (eds.), Mass Communication and Society. London: Edward Arnold.

Hall, S. (1985). Master's session. International Communication Association. Honolulu.

Heinze T., Jappe A., and Pithan D. (2019) Correction: From North American hegemony to global competition for scientific leadership? Insights from the Nobel population. PLOS ONE 14(7): e0219582. https://doi.org/10.1371/journal.pone.0219582. 
INTERNATIONAL JOURNAL OF ACADEMIC RESEARCH IN PUBLIC POLICY AND GOVERNANCE Vol. 7, No. 1, 2020, E-ISSN: 2312-4040 ๔ 2020 KWP

Hough, P., Moran, A., Pilbeam, B., \& Stokes, W. (2015). International security studies: theory and practice. In P. Hough \& M. Shahin, (Eds.), China: Security and Threat Perception (pp. 358-366) London: Routledge.

American Diplomacy. (2003). Foreign Policy in the Bush Administration: An Early Report Card. Retrieved from http://americandiplomacy.web.unc.edu/2003/06/foreign-policy-in-the-bushadministration-an-early-report-card/

Ikenberry, G. J. (2014). From Hegemony to the Balance of Power: The Rise of China and American Grand Strategy in East Asia. Journal of Korean Unification Studies, 23(2), 41-63.

IMF. (2019). World Economic and Financial Surveys: World Economic Outlook Database. Retrieved on 2 November 2019 from https://www.imf.org/external/pubs/ft/weo/ 2019/01/weodata/index.aspx Jim, Z. (2018). Israel: Background and U.S. Relations - Congressional Research Service.

John, J. (2014) Strctural Realism - International Relations Theories: Discipline and Diversity.

John, R. (2015) Still the One? The Role of Europe in American Defense Strategy "Foreign Policy Research Institute".

Just Facts. (2020). Quantifying the National Debt. Retrieved March 2, 2020, from https://www.justfacts.com/nationaldebt.asp

Kwan, C. H. (2020). The China-US Trade War: Deep-Rooted Causes, Shifting Focus and Uncertain Prospects. Asian Economic Policy Review.

Lieberthal K., \& Jisi, W. (2012). Addressing U.S.-China Strategic Distrust. John L. Thornton China Center Monograph Series • Number 4 • March 2012. Retrieved from https://www.brookings.edu/wpcontent/uploads/2016/06/0330_china_lieberthal.pdf

Lull, J. (1995). From Media, Communications and Culture: A Global Approach. Columbia University Press.

Lull, J. (1995). Media, Communications and Culture: A Global Approach, Columbia University Press.

Marry, H. (2019). Who or What Is Dow Jones? Retrieved November 12, 2019, from https://www.investopedia.com/ask/answers/who-or-what-is-dow-jones/

Melvyn, P. L. (2005). Cold War and Global Hegemony, 1945-1991. America on the World Stage: Essays from the American Organization of Historians and APActive. Retrieved November 8, 2019, from https://apcentral.collegeboard.org/series/america-on-the-world-stage/cold-war-andglobal-hegemony-1945-1991

Miller, A. L. (2005). A Superpower? No Time Soon. Standard University, Hoover Institution, No. 2. Retrieved April 10, 2020 from https://www.hoover.org/research/superpower-no-time-soon

Miller, L. (2006). China an emerging Superpower? Stanford Journal of International Relations Department of International Relations, Stanford University Retrieved on 09 April 2020 from https://web.stanford.edu/group/sjir/6.1.03_miller.html 18.08.2018.

Mueller, B., \& Ayello, J. G. (2016). How the East was Lost: Institutions and Culture in 16th Century Portuguese Empire. Retrieved November 29, 2019, from https://economics.yale.edu/ sites/ default/files/how_the_east_was_lost_aug_26_2016.pdf

Mueller, B., Ayello, J. G., \& North D. (2017). How the East was Lost: Coevolution of Institutions and Culture in the 16th Century Portuguese Empire.

Nabers, D. (2010). Power, leadership, and hegemony in international politics: the case of East Asia. Review of International Studies 36(04), 1-25

Nye, J. S. (2018). The cooperative rivalry of US-China relations. Project Syndicate, 6 November.

Paul, M. K. (1989). The Rise and Fall of the Great Powers: Economic Change and Military Conflict from 1500 to 2000. New York: Random House, pp. 347-72; R. J. Overy, Russia's War (London: 
INTERNATIONAL JOURNAL OF ACADEMIC RESEARCH IN PUBLIC POLICY AND GOVERNANCE Vol. 7, No. 1, 2020, E-ISSN: 2312-4040 @ 2020 KWP

Penguin Books, 1997); Allan M. Winkler, Home Front U.S.A.: America During World War II, 2nd ed. (Wheeling, IL: Harlan Davidson, 2000).

Quartz Media. (2019). A simple Guide to Exactly How the United Nations is Funded. Retrieved from qz.com/1712054/who-funds-the-united-nations/

Richard, M. (2016). The Rise of China and the Future of the Atlantic Alliance "Foreign Policy Research Institute".

Senate Committee System. (1979). Activities of the United States Army Corps of Engineers in Saudi Arabia: U.S. Congress. Committee on Foreign Affairs. Subcommittee on Europe and the Middle East. 96th Congress, 1st Session, 25 June 1979. Washington, DC: U.S. Government Printing Office, pp.81 [Hearing].

Shujie, Y. (2007). Can China really become the next Superpower? The University of Nottingham, China Policy Institute, Briefing Series, Issues 21.

South China Morning Post. (2019). China's total debt rises to over 300 per cent of GDP as Beijing loosens borrowing curbs to boost growth. Retrieved from https://www.scmp.com/ economy/china-economy/article/3018991/chinas-total-debt-rises-over-300-cent-gdpbeijing-loosens

Straubhaar, J. (1991). Beyond media imperialism: Asymmetrical interdependence and cultural proximity. Critical Studies in Mass Communication, 8, 39-59.

Susan, S. (n.d.), Hegemonic stability theory cited in Wikipedia: Free Encyclopedia. Retrieved on 23 November 2019 from https://en.wikipedia.org/wiki/Hegemonic_stability_theory

Syria war: Russia and China veto sanctions. (2017). BBC News Retrieved from https://www.bbc.com /news/world-middle-east-39116854.

Schmemann, S. (1991). END OF THE SOVIET UNION; The Soviet State, Born of a Dream, Dies. The New York Times. Retrieved from https://www.nytimes.com/1991 /12 /26/ world/end-of-thesoviet-union-the-soviet-state-born-of-a-dream-dies.html

Timothy, P. I. (1981). Creating the Entangling Alliance: The Origins of the North Atlantic Treaty Organization. Westport, CT: Greenwood Press.

Human Rights Watch. (2019). UN: Unprecedented Joint Call for China to End Xinjiang Abuses. Retrieved from http://www.hrw.org/2019/07/10/un-unprecedented-joint-call-for-china-toend-xinjiang -abuses

US Treasury. (2018). US National Debt public/intergovernmental. Retrieved on 15 November 2019 from https://www.treasurydirect.gov/NP/debt/search?startMonth=03\&startDay=31\&start Year $=2005$ \&endMonth=02\&endDay $=23 \&$ end Year $=2018$

Vincent, F. (n.d.). "The Theory of Hegemonic Stability." Retrieved on 1 October 2019 from http://www.mtholyoke.edu/acad/intrel/pol116/hegemony.htm.

Vinnie. (2019). The theory of Hegemonic Stability. Retrieved November, 2019 from https://www.mtholyoke.edu/acad/intrel/pol116/hegemony.htm

Wilkins, B. (2019). Jimmy Carter: US 'Most Warlike Nation in History of the World. Former president says peaceful China 'ahead of us in almost every way.' Retrieved on April 15, 2020, from https://defence.pk/pdf/threads/jimmy-carter-us-most-warlike-nation-in-history-of-theworld.645637/

William I. H. (1998). France Restored: Cold War Diplomacy and the Quest for Leadership in Europe, 1944-1954. Chapel Hill: University of North Carolina Press. Retrieved February 20, 2020 from https://uncpress.org/book/9780807847473/france-restored/ 
Williams, R. (1976). Key Words: A Vocabulary of Culture and Society. New York: Oxford University Press.

Woetzel, J., Seong, J., Leung, N., Ngai, J., Manyika, J., Madgavkar, A., Lund, S., \& Mironenko, A. (2019, July). China and the world: Inside the dynamics of a changing relationship. Mckinsey Global Institute. Retrieved November 10, 2019, from https://www.mckinsey.com/ /media/ mckinsey/featured\%20insights/china/china\%20and\%20the\%20world\%20inside\%20the\%20d ynamics\%20of\%20a\%20changing\%20relationship/mgi-china-and-the-world-full-report-june-

Zou, Y., \& Jones, L. (2020). China's Response to Threats to Its Overseas Economic Interests: Softening Non-Interference and Cultivating Hegemony. Journal of Contemporary China, 29(121), 92108. 